Supplement of Hydrol. Earth Syst. Sci. Discuss., 12, 11449-11484, 2015

http://www.hydrol-earth-syst-sci-discuss.net/12/11449/2015/

doi:10.5194/hessd-12-11449-2015-supplement

(c) Author(s) 2015. CC Attribution 3.0 License.

(c) (i)

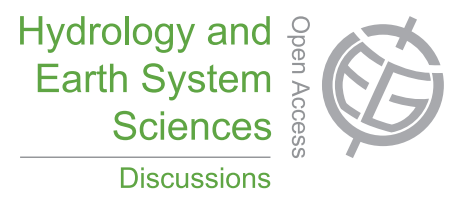

Supplement of

\title{
Analysis of the drought resilience of Andosols on southern Ecuadorian Andean páramos
}

\author{
V. Iñiguez et al. \\ Correspondence to: V. Iñiguez (vicente.iniguez@ucuenca.edu.ec)
}

The copyright of individual parts of the supplement might differ from the CC-BY 3.0 licence. 


\section{Supplementary material}

Dotty plots to analyse the sensitivity of the parameters involved in the soil water balance calculations

Figures (a) and (b) correspond to Calluancay. Figures (c) and (d) correspond to Cumbe. NSE is the NashSutcliffe efficiency (max: 0.74 for both catchments). The blue points show the calibrated parameters for each catchment. The number of simulations was 10000.

(a)

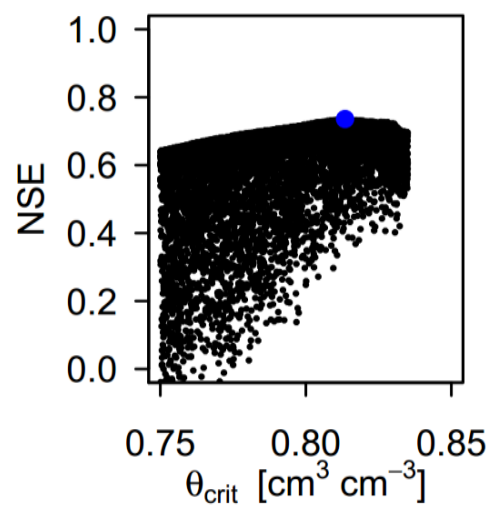

(c)

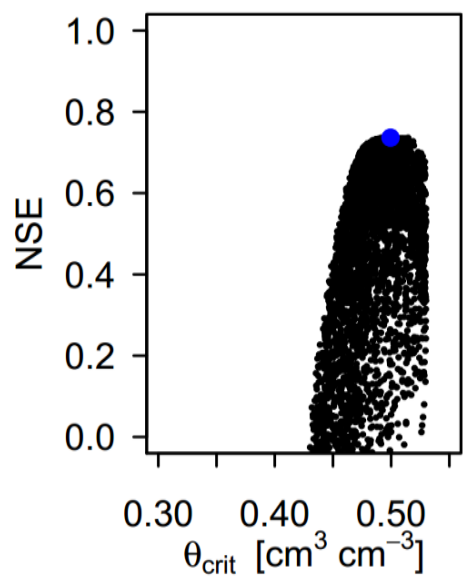

(b)

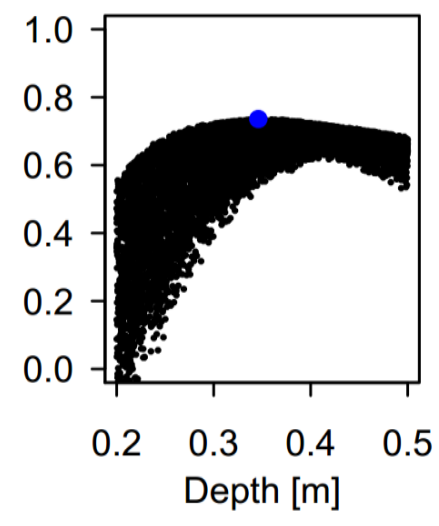

(d)

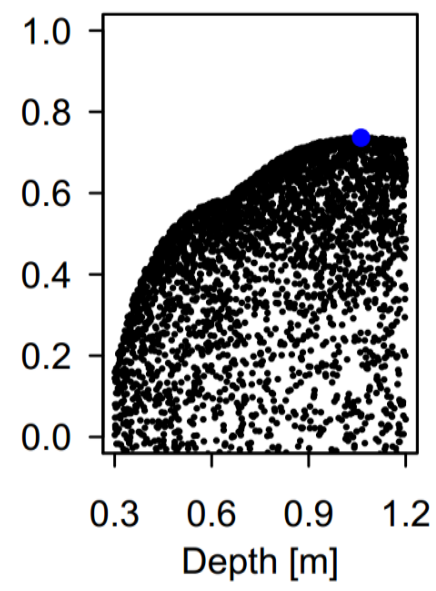

